\title{
The outsiders looking in!: EU and diaspora journalists' reflections on journalistic roles in British press coverage of the EU Referendum
}

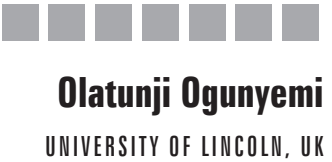

DOI: 10.19195/1899-5101.11.1(20).3

\begin{abstract}
Scholarly research into journalists as a subject of study is increasing. Through this, scholars found there is no consensus among journalists about journalistic practice. This is because journalistic roles are discursively recreated, reinterpreted, appropriated, and contested. The coverage of the EU referendum in the UK provides an opportunity to further explore journalistic roles through a focus group of EU and diaspora journalists and academics. The study reveals that participants were critical of the roles played by the British press in the coverage of the referendum and that they were concerned about its effects on their physical and emotional well-being. Hence, they urge media organisations to offer support and training to redress these concerns. In conclusion, the study provides an in-depth and intense probing of journalistic roles and their effects in relation to the coverage of the EU referendum.
\end{abstract}

KEYWORDS: professional ideology, role conceptions, production practice, EU referendum, framing.

\section{INTRODUCTION}

Journalists play an important role in entrenching the democratic process and empowering citizens to exercise their civic duties. These roles are multifaceted, but they are encompassed in Weaver \& Wilhoit's $(1986 ; 1996)$ classification of professional roles, that is, disseminator, interpretive, adversarial and mobiliser. In discharging their duties, journalists perform one or a combination of these roles which are evident in the coverage of the $2016 \mathrm{EU}$ referendum in the UK, as we shall see in the preliminary scholarly investigations on the coverage. Meanwhile it is pertinent to note that, the dissemination role refers to the provision of objective news or separation of facts from opinions; the interpretive role refers to the provision of analysis and interpretation; the adversarial role refers to being sceptical adversaries to government and business news sources; and populist mobiliser role gives their 
readers a voice in the media and encourages them to be actively involved in community affairs (ibid.; Weaver et al., 2006; Watson, 2014).

In addition, further studies have discovered role conceptions which are different or complementary. The former is a marketing role found in Brill's (2001) study of online journalists which refers to 'the function of competition and appealing to a large audience' (ibid., p. 36). The latter is populist disseminator, detached watchdog, critical change agent, and opportunist facilitator found in Hanitzsch's (2011) study of journalists across 18 countries. These indicate that while journalists subscribe to shared professional values, they discursively recreate, reinterpret, appropriate, and contest them. For instance, Ogunyemi's study (2012) of African diaspora journalists found that they are sensitive to the cultural sensibilities of their audience which suggests an inclination towards disseminator and interpretive roles. While Skjerdal's (2011) study of Ethiopian diaspora online journalists suggests they embrace mobiliser and adversarial roles by promoting citizen involvement and pushing for political change (Skjerdal, p. 729). These sample studies show that while journalists share the tenets of professional role conceptions, there is evidence of a diversity of approaches, interpretation and application depending on their cultural, ethnic, and educational backgrounds.

The growing literature on journalistic roles primes us to focus on journalists as a primary purveyor of news in order to have a deep understanding of factors impacting on news construction and their professional and emotional effects on journalists. This is a pertinent research inquiry because research on the product of journalism has overshadowed research on them as purveyors of news. In the case of the EU Referendum for instance, we know more about media representation and the analysts' opinions of it than the perspectives of journalists, especially the EU and diaspora journalists who work at the margins of the UK mainstream public sphere. Most EU journalists are members of the Foreign Press Association (FPA) which claims to 'vet and provide official journalistic accreditation to more than 1,700 international correspondents every year' (FPA website). The EU journalists in the UK are foreign correspondents working for media in their home country. Some of those who participated in this study work for Die Zeit, a German national broadsheet weekly newspaper published in Hamburg, Germany since 1946 and has a circulation of 520,000 (Die Zeit website). Some work for the Austrian News Magazine, a weekly published in German but based in Vienna, Austria and has a circulation of 135,875 (Austrian News Magazine website).

Diaspora journalists in the UK work for media by and for diasporic groups including Indians, Afro-Caribbean, and Pakistanis who are the largest groups; and Jews, Black Africans, Bangladeshis, Chinese, Roma/Gypsies, Cypriots, Irish, and Vietnamese who are the minority groups (Georgiou, n.d.). Some of those who participated in this study work for the London-based Media Diversified, Short Wave Radio Africa and Bright Entertainment Television. The Media Diversified is a social enterprise working to enrich, engage, and improve the UK's media landscape. 
It was founded in 2013 and aims to challenge the homogeneity of voices in the UK news media, through addressing the under-representation of BAME communities (Media Diversified website). Short Wave Radio Africa claimed to be an independent voice of Zimbabwe but was defunct in 2014 (SW Radio Africa archive). Bright Entertainment Television (BENTV) claims to provide a general black-oriented, youthful and diverse cultural-educational programming format along with its enlightening current affairs shows which serve to throw light on issues plaguing the African and Caribbean Continents (BENTV website).

Despite some differences in their news agenda as elucidated above, it is pertinent to bring these journalists together for this study because they were more or less bystanders in influencing debates about the EU referendum which took place on June 24, 2016; their voices were marginalised and excluded from the mainstream discourse during the campaign; they are more likely to contest the framing of the campaign; and they are more likely to feel the after-effects. The outcome of the referendum showed a slight majority $51.9 \%$ voted to leave the EU as against $48.1 \%$ who voted to remain. This caused a ripple effect across the political, economic, and social landscapes. In the political terrain for example, David Cameron resigned as Prime Minister in July 2016 and his successor, Theresa May, triggered Article 50 in March 2017 to begin a two-year countdown to Britain's departure from the EU and, subsequently, called a snap general election for 8 June 2017 to strengthen her hand in negotiating Brexit terms with Europe. In the economic terrain, while the predicted economic downturn has not materialised, economic analysts are warning that barriers to trade and banking could stifle economic growth. In the social terrain, the fate of over 3 million EU residents in the UK is hanging in the balance with no immediate solution.

While we have some understanding of journalists' roles in furthering democracy and their impact on public opinions and attitudes, we have little understanding of journalistic roles from the perspectives of journalists regarding contentious civic issues. This study aims to provide an insight into this through a case study of the coverage of the EU referendum.

\section{Journalistic roles, referendum and consequences}

Journalistic roles refer to a 'set of the parameters of what is appropriate or acceptable action in a given context' (Hanitzsch \& Vos, 2017, p. 120). However, these parameters are discursively recreated, reinterpreted, appropriated, and contested because the ideals that underpin them are 'ambivalent and liquid' (Koljonen, 2013, p. 141) and because journalistic professionalism is a 'problematic concept that is vulnerable to the values of different interest groups' (Reese, 2001). As a result, previous studies found more disagreement across societies over the relative importance of journalistic roles (Weaver, 1998; Weaver \& Willnat, 2012; Hanitzsch \& Vos, 2017). These ideals refer to the shared occupational ideology which has been categorised into five ideal-typical traits or values, that is, public service, objectivity, 
autonomy, immediacy, and ethics (Kovach \& Rosenstiel, 2001; Deuze, 2005). However, scholars found a lack of consensus as 'journalists in elective democracies share similar characteristics and speak of similar values in the context of their daily work, but apply these in a variety of ways to give meaning to what they do' (Deuze, 2005, p. 445). Similarly, the comparative study by Hanitzsch et al. (2011) of journalists in 18 countries found that 'western journalists are generally less supportive of any active promotion of values, ideas, and social change, and they adhere more to universal principles in their ethical decisions. Journalists from non-western contexts, on the other hand, tend to be more interventionist in their role perceptions and more flexible in their ethical views' (ibid., p. 273).

Hanitzsch \& Vos (2017) propose two analytically distinct levels of journalistic roles to show how they are interlinked. The first level is role orientations which encompass normative and cognitive roles and the second level is role performance which encompasses practiced and narrated roles (ibid., p. 130). They explained that normative roles drive cognitive roles (internalisation), which then translate into practice (enactment) and into corresponding professional and public narratives about journalistic performance (reflection) (ibid.). From this perspective, objectivity is in the domain of normative role orientations and refers to an 'attempt to avoid open value judgments and personal opinion in reporting' (McQuail, 2013, p. 15). But Martin Bell, a former BBC journalist, contested it by stating that 'I was trained in a tradition of objective and dispassionate journalism. I believed in it once. I don't believe in it anymore' (ibid., p. 102). As a result, he proposed 'journalism of detachment' which 'is aware of the moral ground on which it operates, that cares as well as knows, and that will not stand neutrally between good and evil, the victim and the oppressor' (ibid., p. 103). However, he was criticised for misconstruing 'the relationship between objectivity and attachment in journalism practice and ignored the potentially bad consequences of attachment' (Ward, 1998, p. 121).

Nonetheless, the political and cultural imperatives are obvious in some studies which found that 'questions around a story's objectivity are more likely to arise when the author of the story, intentionally or inadvertently, starts to challenge common perceptions about what is in the best interest of the country he or she lives and works' (Matsaganis et al., 2011, p. 237). For instance, 'objectivity is more important with the role perceptions that emphasize a representative conception of democracy in which journalists inform citizens about society, whereas it is less important when they emphasize the inclusion of citizens in a public, democratic debate, which is the case in the public forum and the public mobilizer roles' (Skovsgaard et al., 2012, p. 15). And role conception 'assumes that the way journalists understand their role will influence considerably the way they interact with sources and make decisions about news selection and presentation' (Donsbach, 2008). Therefore, role conceptions are 'functions that journalists perceive they should serve in society' (Tandoc \& Takahashi, 2013, p. 4). However, journalists' perceived roles (role conception) does not usually translate into the performance of these roles (role enactment). 
So, how did the British press enact journalistic roles in the coverage of the EU referendum campaign? Two preliminary investigations published in 2016 by the Centre for the Study of Journalism, Culture, and Community, Bournemouth, and by the Reuters Institute highlighted the contradictory roles played by the media in the referendum. For example, the press became, 'a site where representatives of the two sides attempted to win the battle' (Berry, 2016, p. 14) and played 'an agendasetting role... by focusing on particular politicians and issues. Moreover, the press gave prominence to three primary definers (Gove, Farage, and Johnson) who 'gained legitimacy by their status, they were reported on as legitimate social and political actors: what they said, mattered, and what they said, at important points, turned out to be false' (Roberts, 2016, p. 56).

Moreover, some of these studies found the appropriation of impartiality problematic because 'the majority of the press was heavily skewed in favour of Brexit' (Levy et al., 2016a, p. 33). For example, the Daily Express, Daily Mail, Sun, Daily Star, and Telegraph were pro-leave newspapers, and the Guardian, Daily Mirror, Financial Times, and The Times were pro-remain newspapers (Levy et al., 2016b). The broadcast media did not fare better because Deacon's et al. (2016) found that the coverage on BBC1, ITV, Channel 4, Channel 5 and Sky News was one directional, that is, coverage favouring one or other position; that they gave far greater prominence to reporting and quoting the views of citizens; and that three issues dominated the debate, that is, the economy, immigration, and the conduct of the campaign itself (ibid., p. 34). Hence, scholars criticised the media for 'allowing the binary balance between issues and actors to be politically inflected, with a significant imbalance in party perspectives, presenting us with a right-wing rather than a left-wing case for EU membership' (Cushion \& Lewis, 2017, p. 1). And the media was indicted for marginalising 'other major issues including the environment, taxation, employment, agricultural policy, and social welfare' on the one hand; and for 'the narrow range of voices, issues, and opinions that were given prominence in this most crucial political debate' (Harmer, 2016, p. 38) on the other. For example, Harmer (2016) found that 'women accounted for just 25.3 per cent of all individual sources included in television coverage and just $15.4 \%$ in the press' and that campaigners from the Black and Asian Minority Ethnics (BAMEs) were almost invisible.

Professional ethics has been criticised for reflecting western values. The code of ethics refers to rules, written or unwritten, which prescribe how journalists should work to avoid harming or distressing others (Franklin et al., 2005). However, findings from the Worlds of Journalism Study reveal that 'journalists in Southeast Asia, South Asia, and Sub-Saharan Africa regard developmental goals of educating the audience, supporting national development, and advocating for social change as more central to their role than their Western colleagues' (Wasserman, 2017, p. 313). Such disagreement further exposes the disjunction between ethical principles and role enactment. For example, the 'pursuit of objectivity creates a journalistic product that, again overall, is antithetical to the public interest' (Craft, 2017, p. 294). 
Through these preliminary studies, we know that 'there are other factors that shape the production of media content' (Watson, 2014, p. 14) such as 'professional and social contexts in which they work'. For example:

journalists who more strongly endorsed the interpreter professional role used more thematic frames, delving more deeply into the underlying causes and consequences of the BP oil spill... these interpreters were also less likely to use unofficial sources who are most likely to raise critical perspectives, reinforcing officials' explanations over independent, critical perspectives (Watson, 2014, p. 15).

We are also aware of the effects of social media on media content. For example, scholars found that:

journalists place more value on Twitter than Facebook as it relates to professional practice (Santana \& Hopp, 2016, p. 400).

But these studies show that journalists implement common production standards on the one hand; and provide evidence on the other:

supporting the theory that journalistic norms are contextual, shaped by a hierarchy of influences that include global standards and local values such as culture, political climate and religion (Pintak, 2014, p. 482).

However, there was a lack of consensus among scholars about whether journalistic roles influenced the outcome of the referendum. According to Beckett (2016):

it is politicians and the public who set the agenda and that the news media has short-term, shallow but significant effects (Beckett, 2016, p. 49).

He cautions that the audiences are never passive because the public has:

plenty of sources for campaign news if they had the will, time and (sometimes) money (...) there is a range of other influences on people's thinking including non-mediated factors (Beckett, 2016, p. 49).

For example, scholars argue that:

social media is becoming a more powerful force to assist and influence the spread of political ideas and messages (Polonski, 2016, p. 94)

Leading Mullen to declare that the:

2016 referendum could be characterised as the first digital referendum (Mullen, 2016, p. 89).

However, most of these preliminary studies focused on journalists' practice role performance rather than on their narrated role performance. But Wambach's study was an exception which found that journalists are constrained by the organisational structures they are embedded in, the newsroom routines and practices they 
have been socialised into and their personal relationship with EU officials and sources (Wambach, 2016, p. 53).

Related to journalistic roles is the increasing evidence of social and personal consequences of professional practice. Regarding the former, Fenton (2016, p. 57) warns that:

when newspapers lie to bring about referendum results and the regulator is not prepared to stop them, the consequences are socially and politically catastrophic (Vasilopoulou, 2016, p. 114).

This is because:

the Vote Leave employed the immigration frame in their strategies (...) and the Remain camp put forward a one-dimensional campaign focusing on the economy (Vasilopoulou, 2016, p. 114).

Regarding the latter, a pilot study by the National Union of Journalists (NUJ) and the University of Strathclyde (2015) after the Scottish referendum concludes that:

cyberbullying towards journalists has left them fearing for their own personal safety, with some experiencing a form of cyberbullying more than 50 times in the past year (University of Strathclyde, 2015).

In addition, there is a growing awareness that 'journalists immersed over long periods of time with people who have lived through extremes of exploitation, violence, fear, grief and loss are particularly at risk of PTSD' (Tickle, 2017, p. 16). For example, investigations conducted by the Dart Centre for Journalism Trauma (2003) in the US conclude that 'journalists' symptoms of traumatic stress are remarkably similar to those of police officers and firefighters who work in the immediate aftermath of tragedy, yet journalists typically receive little support after they file their stories' (ibid.). As a result, the UN Plan of Action on the Safety of Journalists and the Issue of Impunity (2012) issued a communiqué on journalism safety defined as 'a broad category that extends from preventive, protective and pre-emptive measures, through to combating impunity and promoting a social culture which cherishes freedom of expression and press freedom'.

\section{RESEARCH DESIGN}

The arguments in previous studies are compelling to investigate the reflections of EU and diaspora journalists on the coverage of the EU referendum including their effects on their physical and emotional wellbeing. Hence, a workshop was hosted by the Media of Diaspora Research Group (MDRG) in the School of English and Journalism at the University of Lincoln on 30th November, 2016. Academics coded as AC1, AC2, and AC3 in Table 1 presented papers in the first half of the workshop and moderated the focus group that followed. 
Table 1 shows the participants, their background, and code. The EU journalists were recruited through the Foreign Press Association (FPA) and the diaspora journalists were recruited through the Media Diversified and other African diasporic media organisations. EUJ1 and DJ2 contributed to the focus group by submitting a 500-word reflective piece because they were unable to attend in person. Key aspects of their reflections were presented by the moderators for discussion during the focus group and analysed in the data analysis. The participants coded ACJ describe themselves as such because of their continuing work in the media. The participants coded AC and R1 were included to enrich the quality of discussion and add theoretical perspectives. Coincidentally, there was gender parity with both seven male female participants. Prior consent was obtained from the participants to record and, to ensure anonymity, the relevant code in Table 1 will be used each time they are quoted. The focus group lasted 90 minutes and was transcribed and coded by the researcher.

Table 1. Distribution of focus group participants

\begin{tabular}{|l|l|c|}
\hline \multicolumn{1}{|c|}{ PARTICIPANTS } & \multicolumn{1}{|c|}{ BACKGROUND } & CODE \\
\hline EU journalist & Works for Die Zeit Online & EUJ1 \\
\hline EU journalist & Works for Austrian news magazine & EUJ2 \\
\hline $\begin{array}{l}\text { Diaspora } \\
\text { journalist }\end{array}$ & Works for Media Diversified & DJI \\
\hline $\begin{array}{l}\text { Diaspora } \\
\text { journalist }\end{array}$ & Works for BENTV, London. & DJ2 \\
\hline $\begin{array}{l}\text { Academic/ } \\
\text { Journalist }\end{array}$ & $\begin{array}{l}\text { Works as an academic at the University of Lincoln and as a freelance } \\
\text { journalist for the mainstream press }\end{array}$ & ACJ1 \\
\hline $\begin{array}{l}\text { Academic/ } \\
\text { Journalist }\end{array}$ & $\begin{array}{l}\text { Works as an academic at the University of Salford and worked as } \\
\text { a freelance journalist for the defunct Shortwave Radio Africa, Slough, } \\
\text { UK. }\end{array}$ & ACJ2 \\
\hline $\begin{array}{l}\text { Academic/ } \\
\text { Journalist }\end{array}$ & $\begin{array}{l}\text { Works as an academic at the University of Lincoln and as a freelance } \\
\text { journalist for Die Zeit Online }\end{array}$ & ACJ3 \\
\hline Academic & Works as an academic at the University of Leeds & AC1 \\
\hline Academic & Works as an academic at the University of Lincoln & AC2 \\
\hline Academic & Works as an academic at the University of Lincoln & AC3 \\
\hline Researcher & A researcher at the University of Lincoln & R1 \\
\hline Researcher & A researcher at the University of Lincoln & R2 \\
\hline Researcher & A researcher at the University of Lincoln & R3 \\
\hline Researcher & A researcher at the University of Lincoln \\
\hline
\end{tabular}

Source: Author.

In analysing the qualitative data, the researcher adopts the Altheide (1996) model which states that 'the goal of qualitative research is to understand the process and 
character of social life and to arrive at the meaning and process, seeking to understand types, characteristics, and organisational aspects of the documents as social products in their own right' (ibid., p. 42). Rather than using predetermined categories, the researcher allowed the themes used by participants to describe, explain, visualize, assign meaning, and interpret the media coverage of the EU referendum and its consequences to evolve during the analysis process. Hence, the data was read multiple times during analysis to identify patterns and sub-themes which relate to normative/ cognitive role orientations; practice roles; narrated roles; and wellbeing. The analyses were checked against existing research and literature to ensure theoretical validity.

\section{FINDINGS AND DISCUSSION}

\section{Normative/cognitive role orientations}

A reflective practice is crucial in the context of this study because it is

the process by which journalistic practices - as well as their observation, interpretation, and categorization - are put into narrative form (Hanitzsch \& Vos, 2017, p. 127).

On the coverage's contributing to the proper workings of democracy, ACJ1 argued that

I experienced the Brexit vote from near Boston, Lincolnshire. There is a movement going on that they want something different. So not all of which is based on racism or hatred. But that's not to say there are no people among them with darker motives. One of the things about the freedom of expression is that you have to give a voice you don't like. If 70 percent of people don't want people from Poland to move in, at what point do you say we don't care if you like it or not, we are going to impose it on it. So, Brexit is a democratic outcome of the people in the UK (ACJ1).

\section{However, previous studies found that}

some newspapers have acted irresponsibly, have damaged our democracy and played a pivotal role in creating the crisis we now face (Rowinski, 2016, p. 52).

Most participants discursively reinterpreted objectivity within the context of the coverage of the EU referendum. According to EUJ2:

objectivity is what is expected of us. For instance, my colleague and I went to report in Birmingham and both of us had a different angle on it. None of the angles are wrong. We should not expect from one journalist or newspaper the entire objective reality. People should read widely to make up their mind (EUJ2).

And ACJ1 agreed that:

it is impossible to be truly objective. We all come from varying degrees of preconceived opinion. The nearer you are to the middle line of objectivity, the more likely you are to be persuaded and the farther you are, the more difficult it is to persuade you (ACJ1). 
However, some participants discursively contested the appropriation of objectivity. For instance, EUJ1 notes that:

I was stunned by the so-called 'balanced' reporting of the BBC, balancing truth with lies and, therefore, giving a completely distorted view of the facts and background to the populace. Moreover, most participants felt that there was little coverage in the papers about how people reacted to the vote (EUJ1).

This discursive approach confirms that objectivity is an occupational norm and an object of struggle within the larger struggle of professional jurisdiction over definitions and particular forms of expertise (Schudson \& Anderson, 2009, p. 96; Blaagaard, 2013).

Despite some shortcomings in the British press' appropriation of objectivity, EUJ1 cautions that 'to put the blame for leaving the EU on the media is quite unfair because you could get a lot of information and choose your medium. The $\mathrm{BBC}$ gave voice to both campaigns. I was surprised by how detailed the media covered the debate. The Remain and Leave campaigners went out knocking on doors, 24/7 for weeks and if anyone wants to be informed, you will get information about anything you want to know'. This position chimes with Beckett's (2016) claim that there is a range of other non-mediated factors which influenced people's thinking.

Participants also discursively contested professional ethics. According to EUJ3:

most of my colleagues said they could not be politically active against Brexit because of their professional ethics, but I think your opinion should not compromise your coverage. You can work for the Financial Times and be pro-EU. We reached a point to think about how to engage in the Brexit debate as private people which has nothing to do with our coverage (EUJ3).

\section{However, ACJ1 countered that:}

I don't think the coverage makes you rethink ethics, you do what you think is fair, accurate, and in the best interests of your community. Brexit was a popularity vote, not a vote on what is right. So, for me ethically, I ended up making a decision for the wrong reason, although the right decision (ACJ1).

This discourse chimes with the claim that 'normative journalistic roles are socially negotiated and sensitive to context' (Hanitzsch \& Vos, 2017, p. 125). Notwithstanding, ethics remains 'an emblem of news-workers' legitimacy when reporting on complex events involving the wants and needs of different media, different people, and different ways to be inclusive' (Deuze, 2005, p. 458).

\section{Practised role performance}

Practised role performance captures

the institutional roles of journalists as they are executed in practice (Hanitzsch \& Vos, 2017, p. 126). 
In the context of the EU referendum, most participants agreed that the British press gave prominence to advocacy and dissemination roles. However, ACJ1 argued that:

the newspapers were so obviously partisan. I could have told you the stance of each of the newspapers two weeks before the referendum. Most of them are advocates for one side or the other (ACJ1).

This chimes with the conclusion of Eriksson \& Ostman's (2013) study on the power relations between journalism and political actors that the interactional phase is characterised more by cooperativeness than aggressiveness; that journalists appear to seek information more than confrontation.

However, the diaspora journalist participants were concerned about hindrances posed by elite officials to their professional practice. According to DJ1:

trying to get information from the official campaign is very challenging and it predates Brexit. You have some journalists that are part of the press lobby and the diaspora journalists struggle to get information from the centre of power or interfacing with the government (DJ1).

\section{And DJ2 added that}

for reasons one cannot explain, government institutions most often, based on our experience, diplomatically turn requests for information down and also shut us out of key government engagements (DJ2).

Moreover, DJ participants were concerned about gender issues. For instance, DJ1 recalled that:

I had a discussion at the $\mathrm{BBC}$ and took them to task on lack of women and they said the campaigns did not put women forward. Well, I think it was a lame excuse (DJ1).

These concerns suggest that diasporic media are, sometimes, hindered in their efforts to achieve diversity.

Literature notes that:

when content is used as a proxy for journalistic practice, the empirical reference points shifts from the individual journalists to the news text (Hanitzsch \& Vos, 2017, p. 126).

In the context of the EU referendum, the participants identified the use of some metaphors and misinformation including 'divisive, exclusive, simplistic, negative, issue focused, individualistic, competitive, differences of opinion, driving a wedge, financial motives, sensationalist, and xenophobic language'. In addition, most participants noted the racist undertone in the coverage. According to ACJ2:

I found the post-election environment alarming and frightening. It is fascinating in terms of the language employed in the Brexit campaign, presented as the economic concern of the elite and 
the economic class. That is very alarming, even though the campaign galvanised a lot of working class to vote, but it was a middle-class thing as well (AC2).

And AC3 agreed that:

I can relate to that too. It is reaffirming old beliefs. Prejudices against homosexuals and other races are interconnected. It evokes distress and rage. Our way of life is being threatened and something far more fundamental was going on (AC3).

As a result, ACJ2 argued that:

the campaign really amplified a certain anti-migrant into an EU migrant which is something mostly felt by the Commonwealth migrants (AC2).

And EUJ2 added that because:

foreign media tend to see Britain as xenophobic and reserved; editors are hesitant for us to write about other things that don't fit the schemata (EUJ2).

Such criticism chimes with Wambach's caution that:

in the coming weeks and months, journalists will be accused of fuelling the toxic tone of the referendum campaigns (2016, p. 53).

Narrated role performance

The narrated role performance denominates

subjective perceptions of and reflections on the roles that journalists carry out in practice (Hanitzsch \& Vos, 2017, p. 127).

On this issue, the participants agreed that their professional identity is core to their sense of belonging to a professional community and that they have no problem self-identifying as practising journalists. However, some participants feel that their professional identity is undermined by polarisation and political correctness. According to EUJ1

I now see the polarisation and fierce journalism on the one side and political correctness on the other side in the UK and the US which is deeply worrying. As a result, my identity and life as a diaspora journalist has changed profoundly in recent years (EUJ1).

It is pertinent to note that EU journalists normally don't describe themselves as 'diaspora journalists', but it seems Brexit has made some to rethink their identity. Nonetheless, their reflections are part of the essential process of maintaining a 'conceptually coherent understanding of what journalism is in an increasingly complex and liquid modern society' (Deuze, 2005, p. 455; Bauman, 2000). 


\section{Wellbeing}

Most participants noted the effects of the coverage of the EU referendum on their physical and emotional wellbeing. On the former, the data shows that the experiences of EU and diaspora journalists were different. For instance, the experience of EU journalists was convivial. According to EUJ2,

I have never been attacked or abused. I had a wave of support from the British because of our political activism and people apologising that I am ashamed of my country (EUJ2).

However, the experience of diaspora journalists was grim. According to DJ1:

I have endured verbal and online abuse because of my writing. Some casual comments have been made in the supermarket when a man retorted 'we voted to get rid of you lot'. It is very unsettling, even though he may have made it as a joke, but the timing was wrong (DJ1).

But a concern about physical safety was palpable in the experience of ACJ2 who narrated that:

I thought I knew what feeling distressed was until I got the news of the result. As an immigrant, I found something inscribed on my bin, it was 'black wanker' and my car was pelted with mud and I called the police and people insulted me and I responded but they called the police and I was arrested for assault. I feel like a black peg in a white hole (ACJ2).

And some other participants recalled their feeling of physical discomfort. According to R2,

I felt sick, that my identity as a European has been robbed from me (R2).

This feeling was echoed by AC2 that:

I felt sick when I heard the result of the vote because I felt that something fundamental that I believe in is no longer true. This is a physical reaction to the result. The way to proceed is togetherness, strong in diversity. But the vote pulled the rug from under my feet. I still feel upset about it (AC2).

Some participants reflected on its effects on their emotional wellbeing. According to DJ1:

I feel a deep sense of betrayal. I have been involved within the Black and Asian Minority Ethnics (BAME) community talking about it, but there was ambivalence within the community. I have seen fellow migrants ready to vote for Brexit which shocked me (DJ1).

Hence, $\mathrm{AC1}$ retorted that:

one of the impacts of Brexit is to make millions of people who are resident in the UK feel less safe and at home (AC1). 
But despite this unpleasant experience, none of the participants felt they have been driven to:

choose to self-censor, avoid contentious stories, or stop using social media in order to avoid their abusers (University of Strathclyde, 2015).

However, the findings in previous studies noted earlier suggest that their physical and emotional experiences are not isolated cases but an unfortunate trend in journalistic practice. Hence, the Dart Centre for Journalism (2003) exhorts that 'in today's society in which terrorism has become even more of a threat, journalists and their supervisors must be aware of possible safety and ethical issues'. This implies that news media organisations need to provide a support mechanism for ensuring the safety of journalists. The participants reflected on this to identify weaknesses in media and journalist's capacity and recommended how these can be (Frohardt \& Temin, 2003; Singh, 2013). For example, they would like to see a stronger implementation of ethical standards with a commitment to inform 'comprehensively, thoughtfully, conscientiously, not distorting news, doing thorough research of different opinions'. They would also like the UK National Union of Journalists (NUJ) to take a more active role in conducting research about the effects of reporting on journalists and identifying training needs. Media organisations have a role to play to protect journalists, reduce stress among them and establish collegial support. Significantly, they would like to see the media play more roles in tackling violent racism and racism in general. And finally, they would like the media to lay down a standard for good journalism underpinned by research, evidence and interpretations.

\section{CONCLUSION}

This study explored the reflections of EU and diaspora journalists on the coverage of the EU referendum by the British press and its effects on their professional and emotional wellbeing. This is because

seasoned journalists may, at some point, be confronted with an inconsistency between their own journalistic experience and what they perceive to be the mainstream view among their peers (Hanitzsch \& Vos, 2017, p. 121).

From this perspective, participants proposed support and training as some of the ways in which media organisations could redress the concerns raised in this study. Hence, this study broadens knowledge about how journalistic roles are discursively negotiated and sensitive to context. It also complements the findings of preliminary scholarly investigations into the coverage of the EU referendum. The implication for practice is that journalists should adopt a sensitive reporting approach when dealing with contentious issues. And the implication for scholarship is that scholars should focus more attention on journalists as subjects of research. 
The limitation of the study was that the participants were not representative of the views of EU and diaspora journalists as only a few were included. Hence, their response may not reflect industry norms and the experience of all EU and diaspora journalists in the UK. Moreover, the participants may be those who have a heightened interest in the issue and belonged to a formally constituted professional association, meaning that the voices of $\mathrm{EU}$ and diaspora journalists working outside of a formal setting were excluded. Therefore, future research should include a wider and diverse group of EU and diaspora journalists to offer important comparisons. While this research did not offer a comprehensive and representative picture of their views on the issue, it provides an in-depth and intense probing of journalistic roles and their effects in relation to the coverage of the EU referendum.

\section{REFERENCES}

Altheide, L. D. (1996). Qualitative Media Analysis. Thousand Oaks, CA: Sage.

Austrian News Magazine. Retrieved on 27 November, 2017 from https://www.news.at/magazin.

Bauman, Z. (2000). Liquid Modernity. Cambridge: Polity Press.

Beckett, C. (2016). Deliberation, distortion and dystopia: the news media and the referendum. In: D. Jackson, E. Thorsen \& D. Wring (eds.), EU Referendum Analysis 2016: Media, Voters And The Campaign. Centre For The Study Of Journalism, Culture And Community. Bournemouth: Bournemouth University,.

Bell, M. (2998). The truth is our currency. The Harvard International Journal of Press/Politics, 3(1), pp. 102-109.

Berry, M. (2016). Understanding the role of mass media in EU Referendum. In: D. Jackson, E. Thorsen \& D. Wring (eds.), EU Referendum Analysis 2016: Media, Voters and the Campaign. Centre for the Study of Journalism, Culture and Community. Bournemouth: Bournemouth University.

Blaagaard, B. B. (2013). Shifting boundaries: Objectivity, citizen journalism and tomorrow's journalists. Journalism. Online First.

Bright Entertainment Television (BENTV). Retrieved on 27 November, 2017 from http://bentelevision.com/about-us/.

Brill, M. A. (2001). Online journalists embrace new marketing function. Newspaper Research Journal, 22, pp. 28-40.

Craft, S. (2017). Distinguishing features: Reconsidering the link between journalism's professional status and ethics. Journalism \& Communication Monographs, Vol. 19(4), pp. 260-301.

Cushion, S., \& Lewis, J. (2017). Impartiality, statistical tit-for-tats and the construction of balance: UK television news reporting of the 2016 EU referendum campaign. European Journal of Communication, Online First.

Dart Centre for Journalism and Trauma (2003). Tragedies and Journalists. A Guide for More Effective Coverage. Retrieved on 2 May, 2017 from www.dartcenter.org.

Die Zeit. Retrieved on 27 November, 2017 from http://www.zeit.de/english/index

Donsbach, W. (2008). Journalists' role perceptions. In: W. Donsbach (ed.), The International Encyclopedia of Communications. Malden, MA: Blackwell, pp. 2605-2610.

Deuze, M. (2005). What is journalism?: Professional identity and ideology of journalists reconsidered. Journalism, Vol. 6(4), pp. 442-464.

Eriksson, G., \& Ostman, J. (2013). Cooperative or adversarial? Journalists' enactment of the watchdog function in political news production. The International Journal of Press/Politics, Online First. 
Fenton, N. (2016). Brexit: inequality, the media and the democratic deficit. In: D. Jackson, E. Thorsen \& D. Wring (eds.), Eu Referendum Analysis 2016: Media, Voters And The Campaign. Centre For The Study Of Journalism, Culture And Community. Bournemouth: Bournemouth University.

Foreign Press Association (FPA). http://www.fpalondon.net/about accessed on 12 May, 2017.

Franklin, B., Hamer, M., Hanna, M., Kinsey, M. \& Richardson, J. E. (2005). Key Concepts In Journalism Studies. London: SAGE.

Frohardt, M., \& Temin, J. (2003). Special Report: Use and Abuse of Media in Vulnerable Societies. Washington, DC: United States Institute for Peace.

Georgiou, M. (n.d.). Mapping Minorities and Their Media: The National Context - The UK. Retrieved on 22 November, 2017 from https://www.slideshare.net/alsaraf1/mapping-minoritiesukreport.

Hanitzsch, T. (2011). Populist disseminators, detached watchdogs, critical change agents and opportunist facilitator. International Communication Gazette, 73, pp. 477-494.

Hanitzsch, T., \& Vos, T. P. (2017). Journalistic roles and the struggle over institutional identity: The discursive constitution of journalism. Communication Theory, 27, pp. 115-135.

Harmer, E. (2016). Brexit 'mansplained': News coverage of the EU Referendum. In: D. Jackson, E. Thorsen \& D. Wring (eds.), EU Referendum Analysis 2016: Media, Voters and the Campaign. Centre for the Study of Journalism, Culture and Community. Bournemouth: Bournemouth University, pp. 38-39.

Koljonen, K. (2013). The shift from high to liquid ideals: Making sense of journalism and its change through a multidimensional model. Nordicom Review, 34, pp. 141-154.

Kovach, B., \& Rosenstiel, T. (2001). The Elements of Journalism. New York: Crown Publishers.

Levy, D., Aslan, B., \& Bironzo, D. (2016a). The press and the referendum campaign. In: D. Jackson, E. Thorsen \& D. Wring (eds.), EU Referendum Analysis 2016: Media, Voters and the Campaign. Centre for the Study of Journalism, Culture and Community. Bournemouth University.

Levy, D., Aslan, B., \& Bironzo, D. (2016b). UK Press Coverage of the EU Referendum. Reuters Institute. Oxford: University of Oxford Press.

Matsaganis, M. D., Katz, V., \& Ball-Rokeach, S. J. (2011). Understanding Ethnic Media. Producers, Consumers and Societies. London: SAGE.

McQuail, D. (2013). Journalism and Society. London: SAGE.

Media Diversified. Retrieved on 27 November, 2017 from https://mediadiversified.org/about-us/.

Mullen, A. (2016). Leave versus Remain: The digital battle. In: D. Jackson, E. Thorsen \& D. Wring (eds.), EU Referendum Analysis 2016: Media, Voters and the Campaign. Centre for the Study of Journalism, Culture and Community. Bournemouth University.

Ogunyemi, O. (2012). What Newspapers, Films, and Television Do Africans Living in Britain See and Read? The Media of The African Diaspora. Lewinston, NY: Edwin Mellen Press.

Pintak, L. (2014). Islam, identity and professional values: A study of journalists in three Muslimmajority regions. Journalism, Vol. 15(4), pp. 482-503.

Polonski, V. (2016). Impact of social media on the outcome of the EU Referendum. In: D. Jackson, E. Thorsen \& D. Wring (eds.), EU Referendum Analysis 2016: Media, Voters and the Campaign. Centre for the Study of Journalism, Culture and Community. Bournemouth University, pp. 94-95.

Reese, S. D. (2001) Understanding the global journalist: A hierarchy of influences approach. Journalism Studies 2, pp. 173-187.

Robert, C. (2016). It's the primary definers, stupid! In: D. Jackson, E. Thorsen \& D. Wring (eds.), EU Referendum Analysis 2016: Media, Voters and the Campaign. Centre for the Study of Journalism, Culture and Community. Bournemouth: Bournemouth University.

Rowinski, P. (2016). Mind the gap: the language of prejudice and the press omissions that led a people to the precipice. In: D. Jackson, E. Thorsen \& D. Wring (eds.), EU Referendum Analysis 2016: Media, Voters and the Campaign. Centre for the Study of Journalism, Culture and Community. Bournemouth: Bournemouth University.

\section{4 - . - . - . - CENTRAL EUROPEAN JOURNAL OF COMMUNICATION 1 (2018)}

Central European Journal of Communication vol. 11, no 1 (20), Spring 2018

(C) for this edition by CNS 
The outsiders looking in!: EU and diaspora journalists' reflections on journalistic roles in British press

Santana, D. A., \& Hopp, T. (2016). Tapping into a new stream of (personal) data: Assessing journalists' different use of social media. Journalism and Mass Communication Quarterly, Vol. 93(2), pp. 383-408.

Schudson, M., \& Anderson, C. (2009). Objectivity, professional and truth seeking in journalism. In: Wahl-Jorgensen, K. \& Hanitzch, T. (eds.), The Handbook of Journalism Studies. New York: Routledge, pp. 88-102.

Singh, S. (2013). Responsible conflict reporting: Rethinking the role of journalism in Fiji and other troubled Pacific societies. Pacific Journalism Review, 19(1), pp. 111-131.

Skjerdal, T. S. (2011) Journalists or activists? Self-identity in the Ethiopian diaspora online community. Journalism, 12(6), pp. 727-744.

Skovsgaard, E. A., Bro, P. \& de Vreese C. (2012). A reality check: How journalists' role perceptions impact their implementation of the objectivity norm. Journalism, Online First.

SW Radio Africa. Retrieved on 27 November, 2017 from http://web.archive.org/web/ 20140915051538/, http://www.swradioafrica.com/.

Tandoc, C. E. Jr., \& Takahashi, B. (2013). Playing a crusader role or just playing by the rules? Role conceptions and role inconsistencies among environmental journalists. Journalism, Online First.

Tickle, L. (2017). In the line of duty. The Journalist, 16-18. April-May.

UN Plan of Action on the Safety of Journalists and the Issue of Impunity (2012). http://www.unesco. $\mathrm{org} / \mathrm{new} / \mathrm{en} / \mathrm{communication}$-and-information/freedom-of-expression/safety-of-journalists/unplan-of-action/ accessed 12 May, 2017.

University of Strathclyde (2015). Cyberbullying leaves journalists fearing for safety. https://www. strath.ac.uk/whystrathclyde/cyberbullyingleavesjournalistsfearingforsafety/accessed on 5 May, 2015.

Vasilopoulou, S. (2016). Campaign frames in the voters' minds. In: D. Jackson, E. Thorsen \& D. Wring (eds.), EU Referendum Analysis 2016: Media, Voters and the Campaign. Centre for the Study of Journalism, Culture and Community. Bournemouth: Bournemouth University, pp. 114-115.

Wambach, A. (2016). They don't understand us: UK journalists' challenges of reporting the EU. In: D. Jackson, E. Thorsen \& D. Wring (eds.), EU Referendum Analysis 2016: Media, Voters and the Campaign. Centre for the Study of Journalism, Culture and Community. Bournemouth: Bournemouth University.

Ward, J. S. (1998). An answer to Martin Bell. Objectivity and attachment in journalism. The Harvard International Journal of Press/Politics, 3(3), pp. 121-125.

Wasserman, H. (2017). Professionalism and ethics: The need for a global perspective. Commentary. Journalism \& Communication Monographs, Vol. 19(4), pp. 313-316.

Watson, R. B. (2014). Assessing ideological, professional and structural biases in journalists' coverage of the 2010 BP oil spill. Journalism and Mass Communication Quarterly, pp. 1-19.

Weaver, D. H. (ed.) (1998). The Global Journalist: News People around the World. Cresskill, NJ: Hampton.

Weaver H. D., \& Wilhoit G. C. (1986). The American Journalist. A Portrait of US News People and their Work. Bloomington: Indiana University Press.

Weaver H. D., \& Wilhoit G. C. (1996). The American Journalist in the 1990s: US News People at the End of an Era. Mahwah, NJ: Lawrence Erlbaum.

Weaver H. D., Beam A. R., Brownlee J. B., Voakes, S. P., \& Wilhoit G. C. (2006). The American Journalist in the 21st Century. US News People at the Dawn of a New Millennium. London: Routledge.

Weaver, H. D., \& Willnat, L. (eds.) (2012). The Global Journalist in The 21st Century. New York, NY: Routledge. 